\title{
Thinking Inclusively About Gifted Education: A Tribute to Judy Lupart
}

\author{
Marion Porath \\ The University of British Columbia
}

It is a pleasure to contribute to this issue's tribute to Dr. Judy Lupart whose distinguished career is highlighted by her important contributions to the education of students with exceptional learning needs. The breadth of her vision and the range of exceptional learning needs she considered in her thinking about inclusive education changed the landscape of special education in Canada and elsewhere. Dr. Lupart articulated the need for systemic change - change that involves deep consideration of the philosophy and structure of systems that welcome all children to an appropriate education in their neighbourhood schools. In this tribute, I focus on the prescient nature of Dr. Lupart's work for the field of gifted education.

A decade before provocative questions were raised about the construct of giftedness and the prevailing "identify and place" model of gifted education (e.g., Barab \& Plucker, 2002; Borland, 2003), Dr. Lupart (1992) began the dialogue about transformation of the dual system of "regular" and "special" education into a unified, inclusive system. Ten years later (Lupart \& Webber, 2002), her work coincided with and informed the closer relationship that now exists between regular and gifted education. This is evident particularly in the attention given to the structuring of rich, creative learning environments that not only have the potential to meet the needs of children whose developmental advancement is obvious but also to "create" gifts and talents (Hymer, 2009) among those children who may not have had opportunities that allowed them to realize their potential. It is also evident in the movement away from the "five box" approach of "referral, testing, labeling, placement, and programming" (Lupart \& Webber, 2002, p. 17) with its emphasis on intelligence testing to an approach that is more flexible, developmentally appropriate, and more equitably matched to students' levels of achievement across the curriculum (see Matthews \& Foster, 2009). Moreover, it is respectful of the diverse backgrounds learners bring to school. Talent development involves consideration of opportunity, cultural perspectives on intelligence and achievement, concomitant learning challenges, personal interests and motivation, and family background (see Katz, 2012). Dr. Lupart's work on inclusion set the stage for thoughtful approaches that ensure all learners have the chance to shine.

A large part of "what matters" in the scope of educational change envisioned by Dr. Lupart is the importance of changing our discourse about children with special needs. The majority of provincial and territorial Ministries of Education websites now prominently feature references to inclusive education and universal design for learning rather than the categorical language associ- 
ated with the "five box" model. This is not to say that language associated with specific exceptional learning needs should be avoided; nor is expertise in understanding particular exceptionalities and providing appropriate education unnecessary. Both were achievements of special education, and they remain important to effective communication and collaborative practice between classroom teachers and educators with sophisticated understanding of exceptional learning needs. They also provide the foundation for teacher education and development that recognizes and honours teaching for the "intricate process" (Lupart \& Webber, 2002, p. 25) it is - a process that allows teachers to discover and support the learning strengths of all their students.

\section{References}

Barab, S. A., \& Plucker, J. (2002). Smart people or smart contexts? Talent development in an age of situated approaches to learning and thinking. Educational Psychologist, 37, 165-182. doi:10.1207 /S15326985EP3703_3

Borland, J. H. (2003). Rethinking gifted education. New York, NY: Teachers College Press.

Hymer, B. J. (2009). Beyond compare? Thoughts towards an inclusional, fluid and non-normative understanding of giftedness. In T. Balchin, B. J. Hymer, \& D. J. Matthews (Eds.), The Routledge international companion to gifted education (pp. 299-307). London, UK: Routledge.

Katz, J. (2012). Teaching to diversity: The three-block model of universal design for learning. Winnipeg, MB: Portage \& Main Press.

Lupart, J. (1992). Toward a unified system of education: Where do we go from here? Exceptionality Education Canada, 2 (1 \& 2), 1-7.

Lupart, J., \& Webber, C. (2002). Canadian schools in transition: Moving from dual education systems to inclusive schools. Exceptionality Education Canada, 12 (2 \& 3), 7-52.

Matthews, D. J., \& Foster, J. F. (2009). Being smart about gifted education. A guidebook for educators and parents. Scottsdale, AZ: Great Potential Press.

\section{Author's Note}

Correspondence concerning this commentary should be addressed to Marion Porath, Faculty of Education, The University of British Columbia, 2125 Main Mall, Vancouver, BC, V6T 1Z4. Email: marion.porath@ubc.ca. 